\title{
Effect of Hybrid Annuity Model on Road Project
}

\author{
Mayur S. Ghayal, Rohit R. Salgude
}

\begin{abstract}
Indian road network is one of the largest road network in world and need huge funding for maintaining and construction of new project. And in India time and cost overrun on infrastructure project are very common. BOT was one of the most successful model from PPP type. But from last couple of years BOT model is lagging behind to achieve financial closure within budget. Most of the BOT project fails due to not generating minimum revenue. Government modifies the MCA (Model Concession Agreement) time to time to eliminate lacunas from existing model. Recent modification of PPP is HAM (Hybrid Annuity Model). Hence to overcome from this type of difficulty government of India introduce the new PPP model called Hybrid Annuity Model (HAM) in 2016. This model was introduce to reduce the financial burden from the contractor. HAM model is a contractual arrangement made by government to overcome the limitations from BOT model. The financial strategy of HAM model is different than BOT model. In HAM model $60 \%$ funding made by authority during construction phase and remaining $40 \%$ is on annuity basis. In this paper the strength and limitation of HAM model is found out and identified most influencing factor for success of HAM model by using Relatively Importance Index (RII) technique. And schematic representation of financial model of HAM is generated by using Model concession Agreement (MCA).
\end{abstract}

Index Terms: Hybrid Annuity Model, Financial model, Relative Important Index, Influencing Factor.

\section{INTRODUCTION}

Government of India introduce the new PPP model i.e. Hybrid Annuity Model (HAM) to reduce financial burden from concessionaire and also to overcome the limitations of BOT toll model. Initially BOT model was the most popular model from PPP. BOT model was widely use in India for road projects and it was the best model which generate initial private funding. In BOT model all initial funding have to done by concessionaire. But from last couple of year BOT model was lagging behind in earlier and on budget project completion. To overcome from such problem government of India develops the Model Concession Agreement and introduce the HAM model.

New PPP model called Hybrid Annuity Model (HAM) in 2016 to overcome the limitations of BOT model and to encourage the contractors to invest money in PPP project. HAM model is contractual arrangement made in such way that it covers all positive and overcome all negative points from BOT model. The major focus of HAM model is on the

Revised Manuscript Received on October 30, 2019.

* Correspondence Author

Mayur S. Ghayal*, Construction Engineering and Management, MIT-WPU, Pune, India.

Rohit R. Salgude, Department of civil Engineering, MIT college Pune, India

(C) The Authors. Published by Blue Eyes Intelligence Engineering and Sciences Publication (BEIESP). This is an open access article under the CC BY-NC-ND license (http://creativecommons.org/licenses/by-nc-nd/4.0/) things that leading BOT model towards failure, like risk of revenue generation, financial viability of project etc. The major changes in HAM model is regarding funding for project where most of the BOT model fails. In HAM model government also invest $60 \%$ money during construction work and HAM model is having equal risk shearing strategy, the risks are allotted properly.

\section{BACKGROUND STUDY}

Sawant; at el, (2018) [1] Land acquisition is a big issue which was not solve by HAM model. There are difficulties in financial closure within budget. HAM model is also lagging behind to overcome issue from BOT model. There is further need to study of HAM model. Kumar (2017) [2] Evolution is a continuous process and MCA is expected to develop further based on the experiences gained by the PPP stakeholders in the industry. Daulatabadi (Dec 2017) [3] If EIRR (economic internal rate of return) is less than $12 \%$ project is not economically viable. If FIRR (financial internal rate of return) is slightly more than $15 \%$ BOT HAM is preferred. If FIRR is close to $18 \%$ BOT toll is preferred. Deshpande (June 2017) [4] Need of effective legislation and dispute resolution board to smooth progress of work. Reddy, (Apr- 2017) [5]PPP fails in generating revenue due to poor pre planning study, Shadow tolling and Hybrid model can be a solutions for such common type of failure. Hande (2017) [6] the most important risk in BOT is change in design and construction work, then the major risk is Loan Risk (bankruptcy), financial issue. kumar; at_el, (March 2017) [7] BOT (Toll), BOT (Annuity) and HAM are the three PPP models that have been used in completing the National Highway projects in India. The selection of the type of PPP models depends on the risk profile and financial viability of the project. Tupe (November 2016) [8] Factors that most affected road users' were higher toll charges, maintenance of roads, and increase in toll rates from time to time. Nile (July 2016) [9] If the NPV value is positive means project fails under acceptance criteria. Mahesh M April (2016) [10] BOT toll is the best model because the risk absorption of increasing traffic is towards contractor.

\section{PROPOSED METHODOLOGY}

\section{A. Data Collection}

The first step is to collect the data to apply Relative Importance index technique to generate hierarchy of most important factor. For study data collection was done from government office.

B. Generating Cash flow Model

Financial model is generated by using Model Concession Agreement and contract document. Schematic representation of cash flow for HAM project is generated 


\section{Identification of most important factor from RII}

Relative important technique is applied on feedback taken from target respondent like government officials', contractors and consultant. The RII gives most influencing factor for successful implementation of Hybrid Annuity Model.

D. Classification of Risk

Risk from Hybrid annuity model is identified from contract document and allocation of those risk according to client and contractor. To identify equal risk shearing attribute.

\section{E. Result and Discussion}

Finally the result generated of RII technique and most important factor for success and most influencing factor for failure from Hybrid Annuity Model is identified. This study helps to successful implementation of HAM model for success of PPP road project.

\section{PROPOSED ALGORITHM}

\section{A. Relative Importance Index:}

The RII is the mathematical toll which is use to analyse the qualitative data or which is use to convert qualitative data into quantitative data. The feedback is taken from target respondent to find out various influencing factor and its influence and impact. The questions was designed so that respondents can give the rank to the question based on their experience and knowledge. For analyse the quality of work from RII technique a questionnaire have to prepare which gives answer of questions on three, four, five, seven, or ten point scale. Based on response from respondent the answer is collected in the form of rating. After that the RII technique is applied on that respond to find the most influencing success and failure factor from contract of HAM.

Formula of Relative Important Index (RII)

$$
R I I=\frac{\sum W}{(A \times N)}
$$

Where:

$\mathbf{W}=$ Weightage given by the respondent to each factor

A= Highest Weightage

$\mathbf{N}=$ Total number of respondent

Table 1 RII Rating Scale

\begin{tabular}{|r|c|c|}
\hline $\begin{array}{l}\text { Sr. } \\
\text { No. }\end{array}$ & Interpretation & Rank \\
\hline 1 & Disagree & 1 \\
\hline 2 & Cannot say & 2 \\
\hline 3 & Moderately Agree & 3 \\
\hline 4 & Agreed & 4 \\
\hline 5 & Strongly Agree & 5 \\
\hline
\end{tabular}

Table no 1 shows the RII ranking and its interpretation. Rank one means disagree on the question asked in questionnaire and rank five means strongly agree with the statement made in questionnaire.

Table 2 List of important factors to achieve the success of HAM model

Sr. Important factor for success of HAM

\begin{tabular}{|c|c|}
\hline No. & \\
\hline 1 & Maintenance of Road \\
\hline 2 & Quality of Maintenance \\
\hline 3 & Penalty for delay in site procurement \\
\hline 4 & Penalty for delay in project \\
\hline 5 & Monthly Progress Report \\
\hline 6 & Involvement of Independent Engineer \\
\hline 7 & Providing 60\% initial funding \\
\hline 8 & Revenue generation policy \\
\hline 9 & Bonus on early Completion \\
\hline 10 & Compensation for change in law \\
\hline 11 & Iratest rate on annuity payment \\
\hline
\end{tabular}

Table no 2 shows most important factor for successful implementation of Hybrid Annuity Model. This factors are identified from the conducting personal interview. The respondent are government officials, contractor and consultants. And person having adequate experience from field of road construction. From the response of respondent eleven most important factor which may concern to successful implementation of HAM model are identified. 
Table 3 RII Data sheet

\begin{tabular}{|c|c|c|c|c|c|c|c|c|c|c|c|}
\hline \multicolumn{12}{|c|}{ Most influencing factor for success of HAM project } \\
\hline \multirow[b]{2}{*}{ 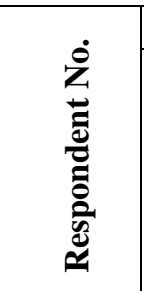 } & \multicolumn{11}{|c|}{ Weightage given by respondent to each factor } \\
\hline & 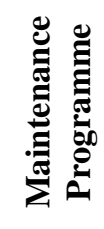 & 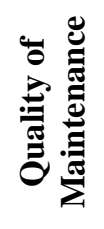 & 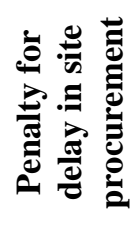 & 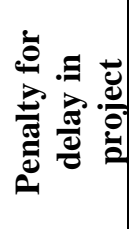 & 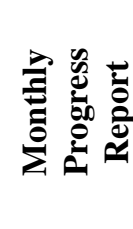 & 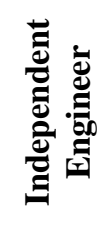 & 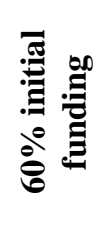 & 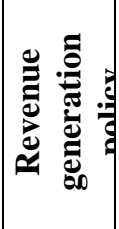 & 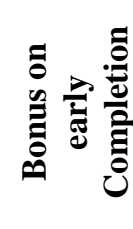 & 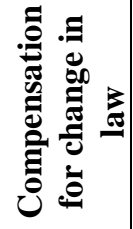 & 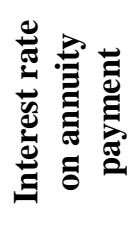 \\
\hline 1 & 3 & 4 & 3 & 4 & 4 & 3 & 4 & 3 & 4 & 3 & 5 \\
\hline 2 & 3 & 5 & 3 & 4 & 4 & 3 & 4 & 3 & 4 & 3 & 3 \\
\hline 3 & 3 & 4 & 3 & 4 & 4 & 3 & 4 & 4 & 3 & 3 & 3 \\
\hline 4 & 2 & 4 & 3 & 4 & 4 & 3 & 5 & 4 & 5 & 5 & 4 \\
\hline 5 & 2 & 4 & 2 & 3 & 4 & 4 & 3 & 4 & 5 & 4 & 2 \\
\hline 6 & 2 & 5 & 2 & 4 & 3 & 4 & 4 & 4 & 5 & 4 & 3 \\
\hline 7 & 2 & 3 & 3 & 3 & 5 & 3 & 5 & 4 & 5 & 4 & 4 \\
\hline 8 & 3 & 4 & 2 & 3 & 5 & 3 & 5 & 5 & 4 & 5 & 3 \\
\hline 9 & 3 & 4 & 2 & 3 & 4 & 4 & 5 & 5 & 5 & 5 & 3 \\
\hline 10 & 2 & 4 & 1 & 4 & 4 & 4 & 4 & 4 & 4 & 4 & 3 \\
\hline 11 & 3 & 4 & 3 & 3 & 4 & 3 & 5 & 4 & 4 & 5 & 3 \\
\hline 12 & 3 & 4 & 4 & 2 & 1 & 4 & 2 & 3 & 3 & 3 & 4 \\
\hline 13 & 3 & 4 & 2 & 4 & 4 & 3 & 5 & 5 & 5 & 5 & 5 \\
\hline 14 & 2 & 4 & 2 & 3 & 4 & 3 & 4 & 5 & 4 & 4 & 3 \\
\hline 15 & 1 & 4 & 3 & 4 & 4 & 4 & 4 & 4 & 4 & 4 & 3 \\
\hline 16 & 3 & 3 & 2 & 4 & 3 & 3 & 5 & 4 & 3 & 5 & 3 \\
\hline 17 & 3 & 4 & 2 & 3 & 3 & 3 & 4 & 4 & 2 & 5 & 4 \\
\hline 18 & 3 & 3 & 1 & 3 & 2 & 3 & 5 & 5 & 3 & 4 & 3 \\
\hline 19 & 2 & 4 & 3 & 4 & 2 & 4 & 4 & 4 & 2 & 4 & 4 \\
\hline 20 & 2 & 4 & 3 & 3 & 2 & 3 & 5 & 5 & 2 & 5 & 3 \\
\hline 21 & 4 & 4 & 2 & 5 & 2 & 4 & 5 & 4 & 2 & 4 & 3 \\
\hline 22 & 2 & 3 & 3 & 3 & 3 & 3 & 5 & 5 & 2 & 4 & 4 \\
\hline 23 & 2 & 3 & 2 & 4 & 2 & 4 & 4 & 5 & 3 & 4 & 3 \\
\hline 24 & 3 & 4 & 3 & 3 & 2 & 3 & 4 & 4 & 2 & 4 & 4 \\
\hline 25 & 4 & 3 & 3 & 3 & 2 & 3 & 4 & 3 & 3 & 3 & 4 \\
\hline 26 & 2 & 4 & 2 & 4 & 4 & 4 & 5 & 4 & 5 & 4 & 3 \\
\hline 27 & 3 & 4 & 2 & 4 & 4 & 4 & 5 & 4 & 5 & 4 & 3 \\
\hline 28 & 3 & 4 & 3 & 3 & 3 & 3 & 4 & 3 & 3 & 3 & 3 \\
\hline 29 & 3 & 3 & 3 & 4 & 2 & 3 & 3 & 5 & 4 & 5 & 3 \\
\hline 30 & 4 & 4 & 3 & 3 & 2 & 4 & 5 & 5 & 4 & 3 & 4 \\
\hline 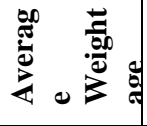 & 2.7 & 3.8 & 2.5 & 3.5 & 3.2 & 3.4 & 4.3 & 4.2 & 3.6 & 4.1 & 3.4 \\
\hline 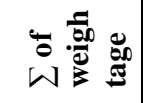 & 80 & 115 & 75 & 105 & 96 & 102 & 130 & 125 & 109 & 122 & 102 \\
\hline RII & 0.53 & 0.77 & 0.50 & 0.70 & 0.64 & 0.68 & 0.87 & 0.83 & 0.73 & 0.81 & 0.68 \\
\hline
\end{tabular}


Table no 3 shows the rating given by each respondent for each factor influencing for successful implementation of HAM project. Total 30 respondent given response for each factor from five point scale starting from Disagree to strongly agree. The RII technique is applied on above table to find out most important factor for success of HAM model.

For Example:

$$
R I I=\frac{\sum W}{(A \times N)}
$$

$\sum$ (Weightage) $\mathrm{W}=80$

(Highest Weightage) $A=5$

(Total no of respondent) $\mathrm{N}=30$

Hence

RII of Maintainance Programe $=\frac{80}{(5 \times 30)}=0.533$

Similarly all calculation for above factor is done to find the importance of each factor then the RII for all eleven factor is identified to find the importance for each factor. Higher rating of RII indicates the more importance of that factor for successful implementation of HAM project.

Table 4 Important success Factor from RII

\begin{tabular}{|c|l|}
\hline RII Rating & \multicolumn{1}{|c|}{ Success Factor of HAM } \\
\hline 0.85 & Bonus on early Completion \\
\hline 0.84 & $60 \%$ initial funding \\
\hline 0.81 & Quality of Maintenance \\
\hline 0.81 & Revenue generation policy \\
\hline 0.81 & Compensation for change in law \\
\hline 0.77 & Monthly Progress Report \\
\hline 0.69 & Penalty for delay in project \\
\hline 0.68 & Independent Engineer \\
\hline 0.68 & Interest rate on annuity payment \\
\hline 0.51 & $\begin{array}{l}\text { Penalty for delay in site } \\
\text { procurement }\end{array}$ \\
\hline 0.49 & Maintenance Programme \\
\hline
\end{tabular}

Table no 4 shows the hierarchy of RII rating for each factor leading towards success of HAM project. Higher the value of RII indicate more importance of that factor. As per RII most important factor for success is Bonus on early completion, $60 \%$ initial funding, revenue generation policy of HAM, and compensation for change in law.

Figure no 1 shows the RII rating vs. important factor for success of HAM project the chart clearly indicate the influence of factor in success of HAM project. The pie chart given below shows the percentage contribution of each factor in success of HAM project. Initial funding bonus on early completion, revenue generation policy and laws regarding change in laws. These four factors contributing $42 \%$ to the success of project. Near about all factor contributing same for success of HAM, it means if any one factor lag behind the schedule, it will not going to make very bad or hazardous impact on project.

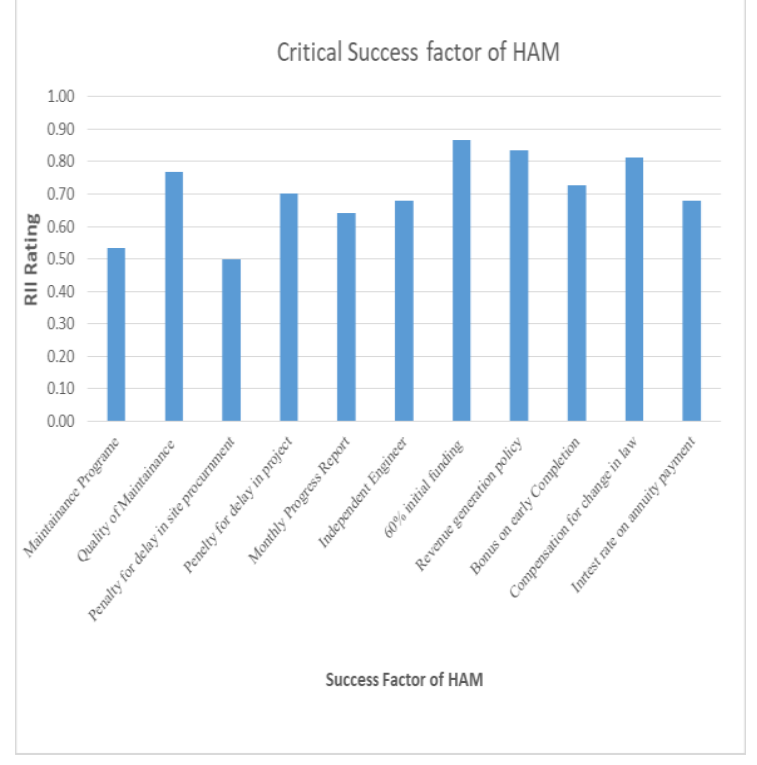

\section{Performance of Each success factor of HAM model}

Table 5 Most influencing failure factor from RII

\begin{tabular}{|c|l|}
\hline RII Rating & \multicolumn{1}{|c|}{ Failure Factor of BOT } \\
\hline 0.87 & $\begin{array}{l}\text { Adjustment of Bid project } \\
\text { cost }\end{array}$ \\
\hline 0.84 & $\begin{array}{l}\text { Responsibility of unknown } \\
\text { Risk }\end{array}$ \\
\hline 0.79 & Performance Security \\
\hline 0.73 & Defect liability period \\
\hline 0.71 & $\begin{array}{l}\text { Excuse from performance of } \\
\text { obligation }\end{array}$ \\
\hline 0.68 & $\begin{array}{l}\text { Modification of maintenance } \\
\text { programme }\end{array}$ \\
\hline 0.67 & $\begin{array}{l}\text { time overrun due to Change } \\
\text { of scope }\end{array}$ \\
\hline 0.65 & $\begin{array}{l}\text { Cost overrun due to change of } \\
\text { scope }\end{array}$ \\
\hline
\end{tabular}

Table no 5 is generated from the RII spread sheet which shows the hierarchy of most influencing factor for failure of HAM project. From which adjustment of BID project cost and responsibility of unknown risk are most critical factor for failure of BOT project. 


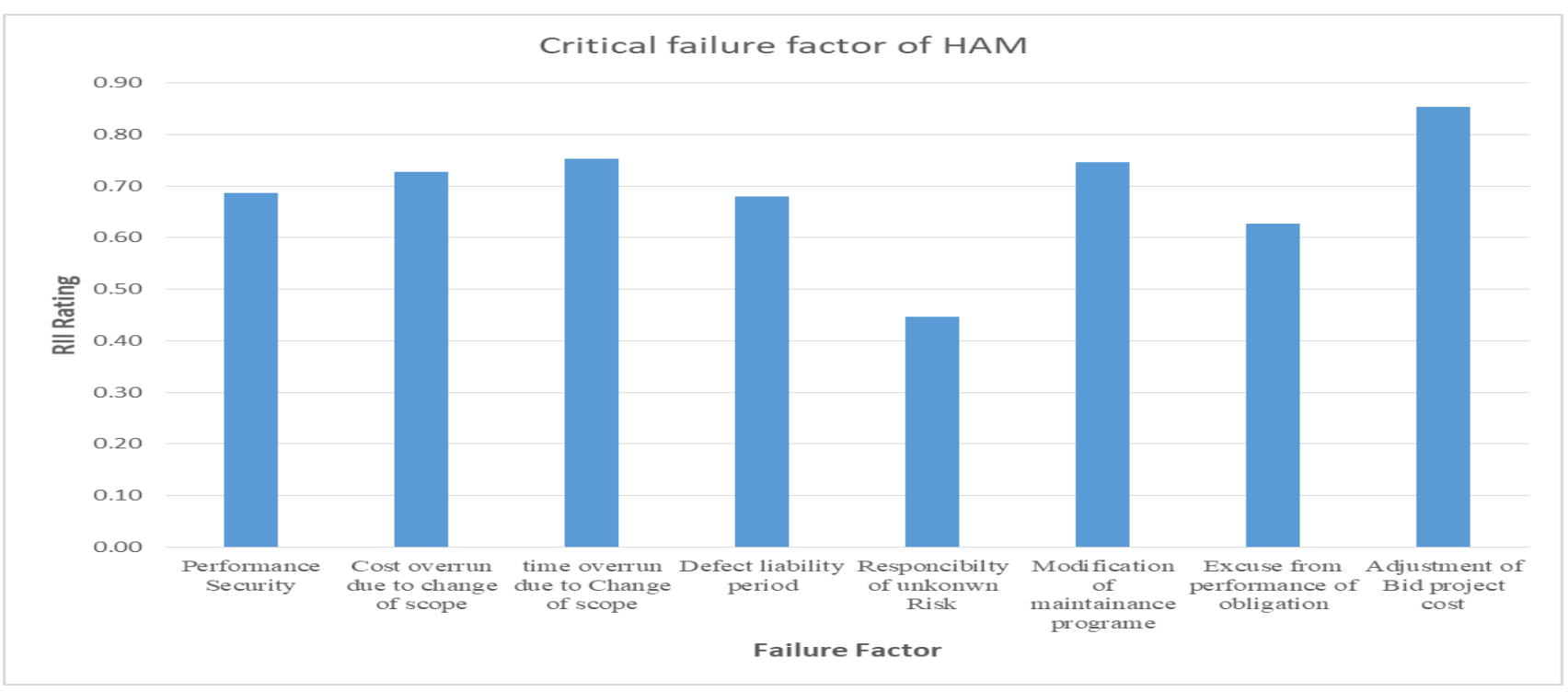

2 Performance measurement of each failure factor of HAM model

Above chart shows the most important factor which affect these factor to achieve the success of HAM project the success of HAM project. Hence it is important to focus

\section{B Generating Cash flow Model}

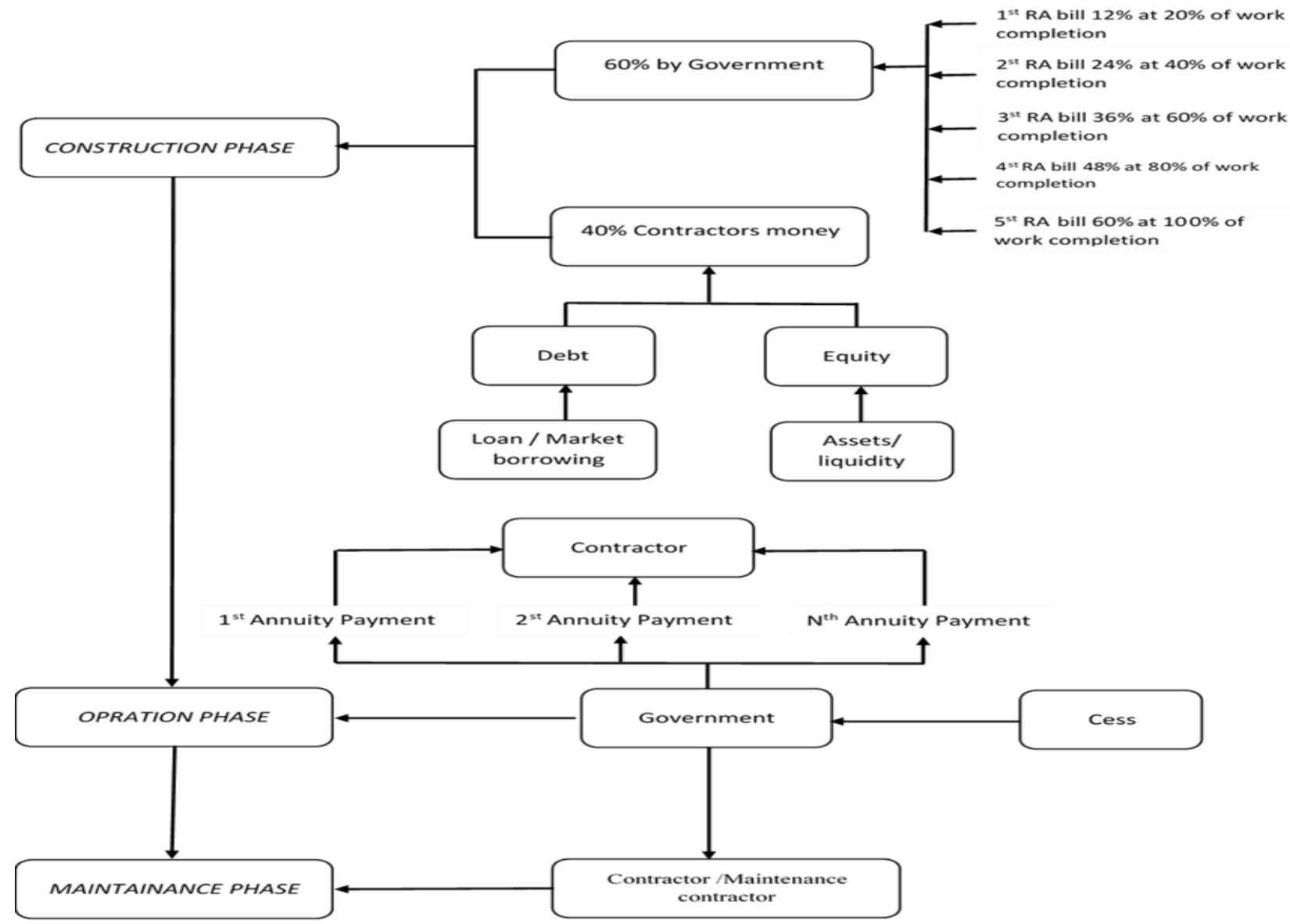

3 Cash Flow structure of HAM

Figure no 3 shows schematic representation of cash flow of Hybrid Annuity model for road project. Which is divided in three phase build, operate and maintenance phase. During the construction phase authority will provide $60 \%$ initial to run the 
project. Initial 60 is given by authority in five equal instalment of every $20 \%$ of work completion. And the $40 \%$ amount have to arrange by contractor either by debt or by equity capital.

During operation phase contractor get his investment back in the form of annuity payment. The authority make fixed annuity payment yearly to the contractor. Revenue is generated from the cess which is plus point of this model. Which increases the financial viability of project. The maintenance of this project is done by main contractor or appointed different maintenance contractor and the maintenance payment is done through the revenue generated.

\section{RESULT AND DISCUSSION}

Table 6 Factors Leading HAM to Success

\begin{tabular}{|c|l|}
\hline Sr. No. & \multicolumn{1}{|c|}{ Most Influencing Success Factor } \\
\hline 1 & Bonus on early Completion \\
\hline 2 & $60 \%$ initial funding \\
\hline 3 & Quality of Maintenance \\
\hline 4 & Revenue generation policy \\
\hline 5 & Compensation for change in law \\
\hline 6 & Monthly Progress Report \\
\hline
\end{tabular}

Table no 6 shows top factors which is strength of HAM model and leading Hybrid Annuity Model to success. Stakeholders involved in project have to focus these factors to achieve easy success of project. $60 \%$ initial funding and bonus on early project completion reduces financial burden from contractor because contractor only have to invest $40 \%$ during construction phase. Then revenue generation policy gives relief to contractor from financial viability of project.

Table 7 Reason for Failure of HAM

\begin{tabular}{|c|l|}
\hline Sr. No. & \multicolumn{1}{c|}{ Failure Factor of BOT } \\
\hline 1 & Adjustment of Bid project cost \\
\hline 2 & Responsibility of unknown Risk \\
\hline 3 & Excuse from performance of obligation \\
\hline 4 & Modification of maintenance programme \\
\hline 5 & time overrun due to Change of scope \\
\hline 6 & Cost overrun due to change of scope \\
\hline
\end{tabular}

Table no 7 shows most frequent reason for failure of HAM. The stakeholders involve in project have to focus these factor to achieve desire success of project. Adjustment of BID project cost and change of scope are most influencing factors in time and cost overrun of project. Then excuse from performance, modification of maintenance program and responsibility of unknown risk affect the quality of project.

\section{CONCLUSION}

1. The financing strategy is the biggest strength of HAM model. Investing more amount at initial stage will reduces the problem related to failure of project due to financial viability.

2. The limitations in HAM model are change of scope, this clause may lead the project to cost and time overrun. But the clause related to change of scope must be required in contract to achieve flexibility about the uncertainty in projects.
3. Problem related with traffic survey and revenue generation are solve by HAM model. Limitation of BOT are either completely solve or modified in HAM

4. HAM model can be the partial solution of common problems from BOT model like not getting minimum revenue and financial viability of project.

\section{REFERENCES}

1. Mithun K Sawant, " Analysis of Hybrid Annuity Model (HAM) For PPP in Highway Project” IJSRD - International Journal for Scientific Research \& Development| Vol. 6, Issue 02, 2018 [ P.NO. 3464 TO 3466].

2. Ankit kumar; "Study of different Public-Private Partnership (PPP) Model for the Road Infrastructure" International Research Journal of Engineering and Technology (IRJET) Volume: 04 Issue: 03 | Mar -2017 [p.no. 2409 to 2412].

3. Atahar Parvez Daulatabadi, Prof. (Dr.) M. Raisinghani; "Model Concession Agreement (MCA) for Highway PPP Projects in India: Evolution and its Various Forms" International Journal for Research in Engineering Application \& Management (IJREAM) Vol-03, Issue-09, Dec 2017, [P. No. 49 to 52].

4. Pawan Deshpande; "Risk Mitigation Strategies for Public Private Partnership Highway Projects in India" International Journal of Civil Engineering and Technology (IJCIET) Volume 8, Issue 6, June 2017, [p. no. 584-594.]

5. N. Srinivasa Reddy, Sharma Pankaj, "Why PPP Modeled Infrastructure Projects Failed:A Critical Review with a Special Focus on Road Sector" International Journal of Advanced Engineering, Management and Science (IJAEMS) [Vol-3, Issue-4, Apr- 2017].

6. Hande Aldag1 and Isik Zeynep2, "Role Of Financial Risk In Bot Megatransportation Project In Developing Countries" ASCE journals @2017, Doi 10.1061/(ASCE) ME 1943-5479.0000527.

7. Ankit kumar, "Study of different Public-Private Partnership (PPP) Model for the Road Infrastructure" International Research Journal of Engineering and Technology (IRJET) Volume: 04 Issue: 03 | Mar -2017 [p.no. 2409 to 2412].

8. Tupe S. N. "Satisfaction of Travelers about BOT Projects: A Case Study of Pimpalgaon-Nasik-Gonde (PNG) Project" international journal of innovative research \& development November, 2016 [p. no. 144 to 148 ]

9. Ganesh R Nile; Prof. P M Attarde, "Investigation of feasibility and Risk in BOT Road project" International Journal of Latest Trends in Engineering and Technology, Vol 7 issue 2 July 2016 (http://dx.doi.org/10.21172/1.72.56)

10. Mahesh M. Barad, Dr. K. Ravi; "Public Private Partnership in Highway Construction in India" International Journal on Recent and Innovation Trends in Computing and Communication Volume: 4 Issue: 4 April 2016 [p.no. 174 to 176].

\section{AUTHORS PROFILE}

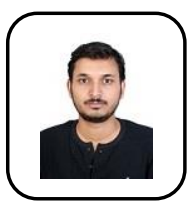

Mayur S. Ghayal Pursuing M.Tech at MIT-WPU, Pune 2017-19. Department of construction Engineering and management

Email-ghayalmayur55@gmail.com

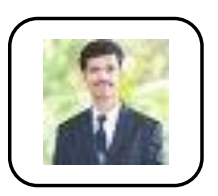

Prof. Rohit $\mathbf{R}$ Salgude Assistant professor, Department of civil engineering MIT Pune Email- rohit.salgude@mitpune.edu.in 